\title{
Quantification of hydrogen cyanide as a potential decomposition product of ethanedinitrile during pine log fumigation
}

\author{
Matthew Hall ${ }^{1,2^{*}}$, Anthony Adlam ${ }^{1}$, Adam Matich ${ }^{1}$, Adriana Najar-Rodriguez ${ }^{1}$, Pranoy Pal ${ }^{1,3}$ and Don Brash
}

\begin{abstract}
Background: The Stakeholders in Methyl Bromide Reduction (STIMBR) are evaluating ethanedinitrile (EDN) as an alternative fumigant to methyl bromide for use as a phytosanitary treatment for pine logs (Pinus radiata D.Don). Ethanedinitrile is hypothesised to decompose into hydrogen cyanide $(\mathrm{HCN})$ in the presence of water. This process, if it occurs, is of particular interest because it may influence the efficacy and emissions data needed for commercialisation.
\end{abstract}

Methods: The concentrations of EDN and HCN were measured in the treated space (28 L fumigation chambers) without $(n=1)$ and with pine log sections $\left(n=3 ; 46 \pm 1.4 \%\right.$ load factor) at 10 or $20^{\circ} \mathrm{C}$ in a simulated commercial fumigation.

Results: On average, the cylinder of EDN tested contained $34.6 \mathrm{~g} \mathrm{~m}^{-3} \mathrm{HCN}$ (or 3.1\%), which corresponds to a concentration of $0.8 \mathrm{~g} \mathrm{~m}^{-3}$ (or $0.07 \%$ ) in the treated space for a $50 \mathrm{~g} \mathrm{~m}^{-3}$ EDN dose (commercial rate in Australia). This level of HCN is likely a result of the manufacturing process, whereby HCN is oxidised to produce EDN. During fumigation, $\mathrm{HCN}$ was detected in the treated space at relatively low concentrations, which did not significantly change over time. This indicates that $\mathrm{HCN}$ is not produced in substantial amounts during fumigation and that, as a result, insect efficacy is unlikely to be affected by low unchanging ( $P=0.055)$ concentrations of this compound in the treated space.

Conclusions: The results of this work support the statement that EDN is not significantly converted to HCN during the treatment of recently harvested pine logs.

Keywords: Cyanogen, Fate, Temperature, Fumigas ${ }^{\mathrm{TM}}$, Breakdown, Sorption, Sterigas ${ }^{\mathrm{TM}}$

\section{Background}

The treatment of commodities with fumigants is the most economic method of disinfestation to kill insects and pathogens (Duarte-Sierra et al. 2016; Fields et al. 2004). Methyl bromide (MB) is currently the most effective fumigant used for quarantine and pre-shipment (QPS) purposes internationally. As $\mathrm{MB}$ is an ozone-depleting compound, its use has largely been restricted globally to QPS treatments. In New Zealand, MB used after 2020 will require its recapture or destruction to limit emissions to the atmosphere (Hall et al. 2017). The search for alternative fumigants to $M B$ identified a relatively new fumigant,

\footnotetext{
* Correspondence: matt@apreso.co.nz

${ }^{1}$ The New Zealand Institute for Plant \& Food Research Limited, Private Bag 11600, Palmerston North, New Zealand

${ }^{2}$ Apreso, Po Box 2407, Palmerston North, New Zealand

Full list of author information is available at the end of the article
}

ethanedinitrile (EDN), as a potential chemical treatment of pine (Pinus radiata D.Don) logs (Brash et al. 2013; Hall et al. 2015). The Stakeholders in Methyl Bromide Reduction (STIMBR) endorsed the collection of data to support the use of EDN as a QPS treatment for export logs.

Sorption is a term used to refer to the adsorption and absorption of fumigant molecules by the commodity being treated, thereby reducing its concentration in the treated space over time (Hall et al. 2017). Brash et al. (2013) reviewed EDN as a potential quarantine disinfestation treatment for logs and sawn timber. They concluded that EDN had potential as a phytosanitary treatment, particularly for sawn timber, where sorption rates were estimated to be lower than that of logs due to the lower moisture content of sawn timber. However, 
EDN is water soluble (Emekci 2010), with $4.5 \mathrm{~L}$ of gas dissolvable in $1 \mathrm{~L}$ of water and the decomposition pathway of EDN to $\mathrm{HCN}$ was unresolved because the patent (O'Brien et al. 1999) states that $\mathrm{HCN}$ is produced in water and high humidity environments. High humidity is expected to occur when recently harvested logs are covered with a tarpaulin and fumigated. Consequently, it was hypothesised that these circumstances would facilitate the decomposition of EDN to HCN. Also, the higher sorption rates of EDN into logs would potentially render this fumigant ineffective for commodities with a high moisture content. The fate of EDN must be considered by the New Zealand Environmental Protection Authority (EPA) during the registration process (EPA-NZ 2012) that will permit the use of EDN in New Zealand.

Park et al. (2014) did not detect HCN in the treated space during the fumigation of Korean red pine (Pinus koraiensis Siebold and Zucc.) logs with EDN. Their results indicated either that the predicted decomposition of EDN to $\mathrm{HCN}$ may not occur during the fumigation of logs or that the production of $\mathrm{HCN}$ occurred at levels that were undetectable with the gas chromatography system they used. Moreover, if $\mathrm{HCN}$ is not produced or produced only at inconsequential concentrations, then the impacts on chemical efficacy, environmental emissions and worker safety issues should be negligible. Also, Pranamornkith et al. (2014b) showed that the moisture content of wood did not significantly influence the sorption rate of EDN over a typical treatment period $(10 \mathrm{~h})$ despite the solubility of EDN in water.

Sorption rates vary depending on a number of factors such as the fumigant, temperature, load factor, moisture content and commodity being treated (Hall et al. 2015; Pranamornkith et al. 2014b). The mode of insecticidal action of EDN is respiratory so a high sorption rate is undesirable (Pranamornkith et al. 2014b) as less of the fumigant is available in the treated space to affect the insects. The results of Pranamornkith et al. (2014b) indicate that EDN may have more potential as a fumigant for the disinfestation of logs than Brash et al. (2013) suggested. Although EDN does have a higher rate of sorption than MB (Hall et al. 2017; Hall et al. 2015), it is highly toxic to forest insects (Pranamornkith et al. 2014a) and more toxic to the burnt pine longhorn beetle (Arhopalus ferus [Mulsant]) than MB (Najar-Rodriguez et al. 2015). Thus, any negative effects of a higher rate of sorption may be offset by the greater toxicity of EDN to insects.

If $\mathrm{HCN}$ is produced during fumigation by the decomposition of EDN as hypothesised (Brash et al. 2013), then this process may either positively or negatively affect the efficacy of EDN as a fumigant. Hydrogen cyanide is also toxic and could, therefore, have insecticidal activity that may either supplement or interfere with the effectiveness of EDN. For example, the CT (concentration $\times$ time) value of $\mathrm{HCN}$ required to kill larvae of the Asian longhorn beetle (Anoplophora glabripennis) is $17.67 \mathrm{~g} \mathrm{~h} \mathrm{~m}^{-3}$ at fumigation temperatures of $23-24{ }^{\circ} \mathrm{C}$ (Stejskal et al. 2014), while the CT value of EDN required to kill larvae of Arhopalus ferus is $19.50 \mathrm{~g} \mathrm{~h} \mathrm{~m}^{-3}$ at $20{ }^{\circ} \mathrm{C}$ (Najar-Rodriguez et al. 2015). Thus, determining the toxicity of both these chemicals to various insects and assessing whether or not their concentrations change in the treated space over time are important factors in understanding the efficacy of EDN as a fumigant. The current study focused on the second of these factors. The concentrations of both EDN and $\mathrm{HCN}$ were measured during simulated fumigations to determine if a significant proportion of $\mathrm{HCN}$ is produced as a breakdown product of EDN when used to treat recently harvested pine logs with a high moisture content.

\section{Methods}

\section{Source and physical characteristics of logs}

Pine (Pinus radiata D.Don.) logs were sourced near Palmerston North, New Zealand (latitude $-40.41^{\circ}$, longitude $175.67^{\circ}$ ), on 5 May 2015. Logs were collected from a commercial stand of 18-year-old trees. Timber sections were cut from the upper trunk of six randomly selected trees to fit into $28 \mathrm{~L}$ fumigation chambers (Labconco Desiccators, Kansas City, Missouri, USA) with internal dimensions of $305 \times 305 \times 305 \mathrm{~mm}$. These sections were stored at $4 \pm 1{ }^{\circ} \mathrm{C}$ for up to 4 weeks before they were used in experiments. This was done to allow enough time to arrange for the resources required for this experiment. Prior to fumigation, each of these six sections were further cut into smaller sections $(\approx$ $270 \mathrm{~mm}$ long, $\approx 250 \mathrm{~mm}$ diameter) to ensure a load factor $\cong 50 \%$ was established during fumigations. Load factor is the proportion of the treated volume occupied by the material being treated and is typically close to $50 \%$ for logs treated commercially under tarpaulin.

\section{Source of EDN}

The EDN used for these experiments was manufactured by Draslovka, Czech Republic, in May 2010 using a pilot plant. The concentration of $\mathrm{HCN}$ in the cylinder used in this work was determined using the method described below. Draslovka does not expect any decomposition of EDN in the cylinder over 5 years of storage until its use for the current study (Adam Jonas, Draslovka; personal communication).

\section{Experimental design}

A two-factor, randomised block design was used to determine the relationship between EDN and HCN during fumigations, with temperature (at two levels, 10 or $20{ }^{\circ} \mathrm{C}$ ) and time since fumigation (at six levels, viz. $0,2,4,6,8$, 
and $10 \mathrm{~h}$ ) as factors. Chambers each at 10 and $20{ }^{\circ} \mathrm{C}$ without logs $(n=1$, i.e. the control $)$ and with logs $(n=3)$ were used to monitor EDN and $\mathrm{HCN}$ concentrations over time. Moisture content of the log sections were calculated on a dry weight basis using the following formula as described by Hall et al. (2017): [(wet weight - oven dry weight) $\times$ $100 /$ (oven dry weight)]. Average moisture content of the $\log$ sections was $141 \pm 9 \%(n=6)$.

The registered dose of EDN Fumigas ${ }^{\mathrm{TM}}$ for the treatment of logs and timber in Australia is $50 \mathrm{~g} \mathrm{~m}^{-3}$ for a treatment period of $10 \mathrm{~h}$ [(BOC n.d.), Australia]. These conditions were replicated in the laboratory to simulate commercial practices by employing a $50 \mathrm{~g} \mathrm{~m}^{-3}$ dose of EDN in either an empty chamber or a chamber with a $\log (46 \pm 1.4 \%$ load factor). This dose was used to determine the influence of log moisture on the potential production of $\mathrm{HCN}$.

A gas-tight 1-L syringe connected to an EDN delivery system was used to transfer $625 \mathrm{~mL}$ of EDN to each treated chamber to produce a dose equivalent to $50 \mathrm{~g} \mathrm{~m}^{-3}$. A fan provided circulation during fumigation to ensure complete gas mixing. The fumigation chambers were housed in temperature-controlled rooms maintained at either 10 or $20 \pm 1^{\circ} \mathrm{C}$.

\section{Measurements and analysis}

Using an airtight gas syringe, gas samples were drawn from the treated space of each chamber at $0,2,4,6,8$, and $10 \mathrm{~h}$ after fumigation. At each sampling occasion, two separate samples were simultaneously collected from each chamber: (1) a 1-mL sample that was analysed by direct injection on a gas chromatograph with a mass-spectrometer detector (GC-MS) to determine the concentration of $\mathrm{HCN}$ and (2) a 3-mL sample that was analysed on a gas chromatograph with a flame ionisation detector (GC-FID) with a $250-\mu \mathrm{L}$ sample loop to determine the concentration of EDN. The MS detector was used to quantify $\mathrm{HCN}$ because the amounts of this compound in the samples were small and the MS detector was more sensitive than the GC-FID detector.

The concentration of EDN in each sample was measured using an Agilent 7890A GC (Santa Clara, CA) equipped with a FID following isothermal separation (at $150{ }^{\circ} \mathrm{C}$ ) on a $30 \mathrm{~m} \times 0.53 \mathrm{~mm}$ internal diameter GS-Q, fused-silica PLOT column (Agilent J\&W). The GC oven, inlet, and detector temperatures were 150, 150, and $300{ }^{\circ} \mathrm{C}$, respectively. The hydrogen, air, and make-up (nitrogen) flow rates were 100,400 , and $0.5 \mathrm{~mL} \mathrm{~min}^{-1}$, respectively, and the total run time was $0.6 \mathrm{~min}$. A seven-point calibration using dilutions of a newer, purer supply of EDN (Draslovka, Kolín, Czech Republic, > 99.5\% pure) in air was performed at the beginning of each measurement period. Concentrations of $0,10,25,35,45,55$, and $90 \mathrm{~g} \mathrm{~m}^{-3}$ were used in preparing calibration curves.
Measurement of $\mathrm{HCN}$ was performed using static headspace sampling and GC-MS, based on the methods of Murphy et al. (2006) and Eaton (2009). Separations were performed on an Agilent $6890 \mathrm{~N}$ GC coupled to a Waters GCT time-of-flight MS with an electron ionisation energy of $70 \mathrm{eV}$ and a scan time of $0.4 \mathrm{~s}$. A gas-tight syringe was used to make 1-mL split-less injections (over c. $30 \mathrm{~s})$ onto a HP-PLOT/Q column $(30 \mathrm{~m} \times 0.32 \mathrm{~mm}$, Agilent Technologies Inc., Santa Clara, CA). The injection port was maintained at $40{ }^{\circ} \mathrm{C}$, and the front of the $\mathrm{GC}$ column at $-30{ }^{\circ} \mathrm{C}$ with a liquid nitrogen cryotrap (GL Sciences Optic3-SC, Veldhoven, the Netherlands). After $90 \mathrm{~s}$, the injection port was ramped from 40 to $150{ }^{\circ} \mathrm{C}$ at $25^{\circ} \mathrm{C} \mathrm{s}^{-1}$; at $120 \mathrm{~s}$, the injection port was changed from a

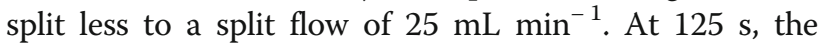
cryotrap was heated to $150{ }^{\circ} \mathrm{C}$ at $50{ }^{\circ} \mathrm{C} \mathrm{s}^{-1}$ and the oven temperature ramp and $\mathrm{MS}$ were triggered. The oven temperature programme was $0.5 \mathrm{~min}$ at $60{ }^{\circ} \mathrm{C}, 11^{\circ} \mathrm{C} \mathrm{min}{ }^{-}$ ${ }^{1}$ to $200{ }^{\circ} \mathrm{C}$, which was held for $1.5 \mathrm{~min}$. A HCN standard (Air Liquide, Melbourne, Australia) was used to determine the response of the GC-MS system. Under these conditions, EDN was eluted at $4.6 \mathrm{~min}$ and $\mathrm{HCN}$ at $5.8 \mathrm{~min}$ (Fig. 1).

\section{Statistical analysis}

The concentrations of EDN and $\mathrm{HCN}$ during the fumigation of log sections were analysed with residual maximum likelihood (REML) repeated measurements using GenStat (14th edition, VSN International, Hemel Hempstead, UK). Temperature and time after fumigation were analysed as factors. The $P$ values and Wald/d.f. values were used to identify those factors (temperature and time) that significantly influenced the concentration of gases during fumigation. Differences between means were expressed as the standard error of the mean.

\section{Results and discussion Identification of HCN and EDN}

The mass-to-charge ratios $(\mathrm{m} / \mathrm{z})$ of 27 and 52 for $\mathrm{HCN}$ and EDN, respectively, are shown in Fig. 2. The relative sensitivity of the GC-MS system combined with the $\mathrm{m} / z$ of these compounds demonstrated that HCN was appropriately separated from EDN identified from the gas samples taken from the treated space during fumigations.

\section{Purity of EDN}

The concentration of $\mathrm{HCN}$ in the cylinder used for fumigations was found to be $3.1 \% v / v$, which is equivalent to $34.6 \mathrm{~g} \mathrm{~m}^{-3}$. When the gas was diluted to supply an EDN dose of $50 \mathrm{~g} \mathrm{~m}^{-3}$, this value equated to $0.8 \mathrm{~g} \mathrm{~m}^{-3}$ (or $0.07 \%$ ) $\mathrm{HCN}$ in the treated space. It is most likely a residue contaminant from the manufacturing process in which $\mathrm{HCN}$ is oxidised to produce EDN. The manufacturer of the EDN (Draslovka) has since constructed a 


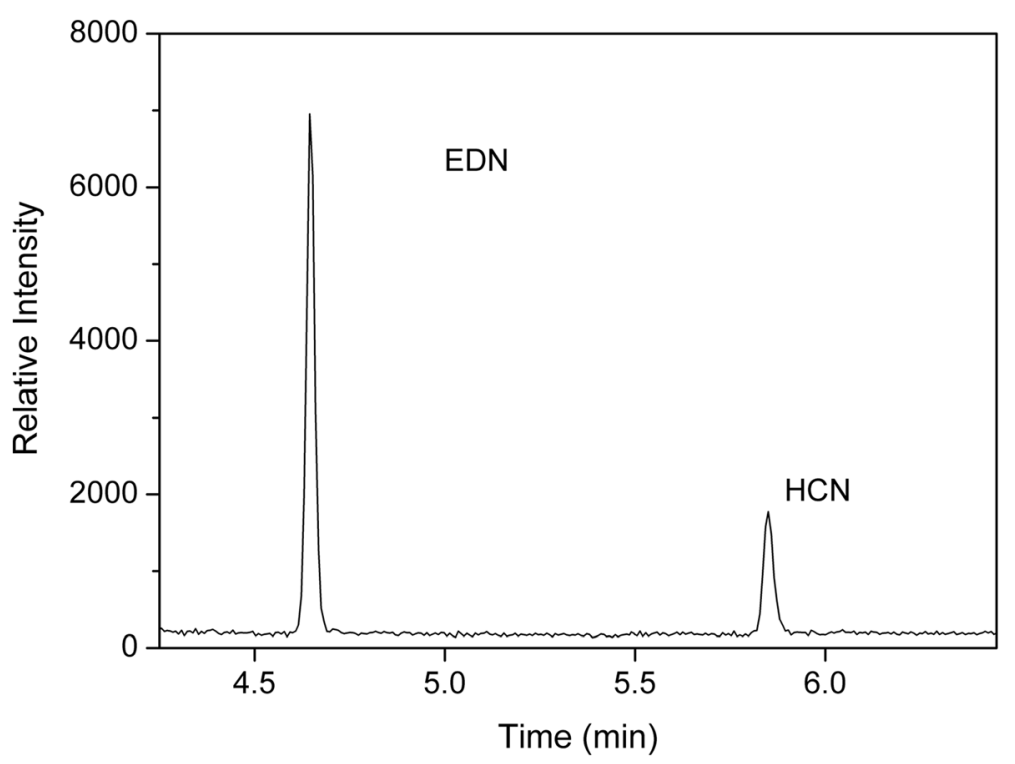

Fig. 1 Retention time and relative intensity of ethanedinitrile (EDN) and hydrogen cyanide (HCN) under the conditions used in this study

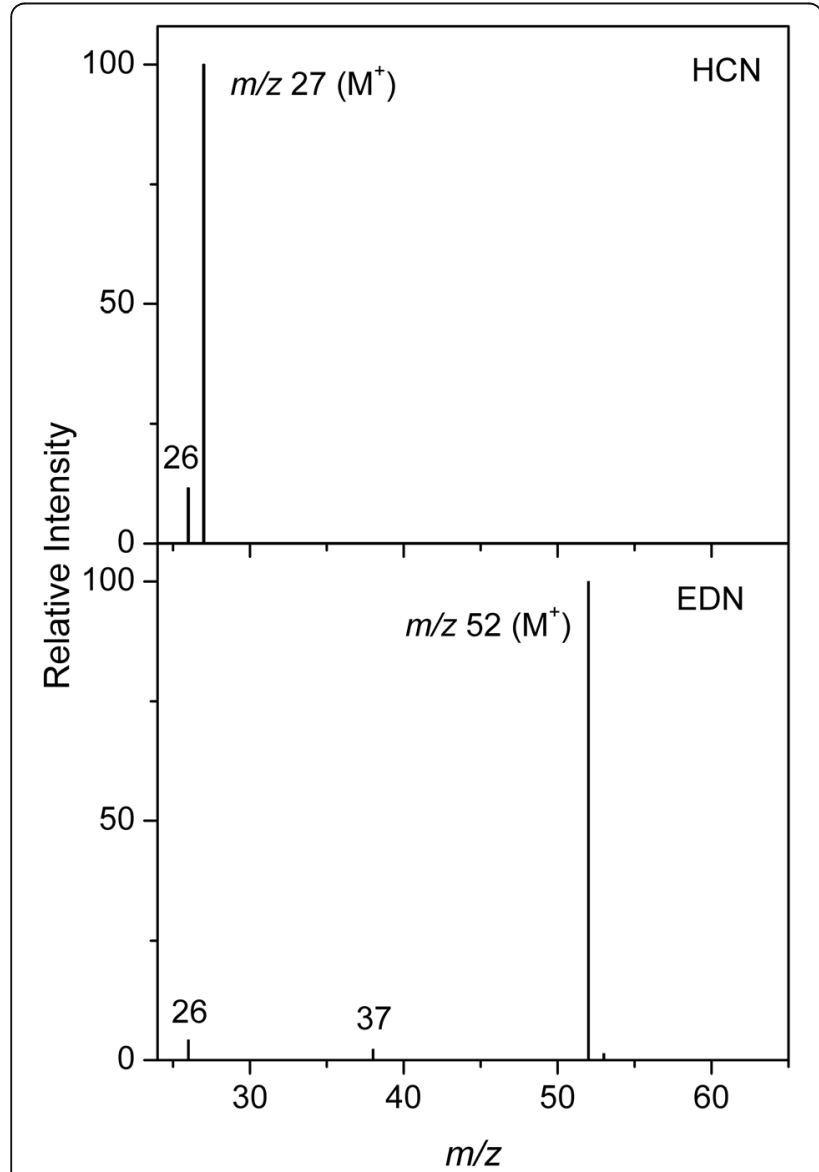

Fig. 2 Mass-to-charge ratio $(\mathrm{m} / \mathrm{z})$ of hydrogen cyanide $(\mathrm{HCN})$ and ethanedinitrile (EDN) showing their respective $\mathrm{m} / \mathrm{z}$ and relative intensity production plant that is capable of supplying EDN with $<0.9 \% \mathrm{HCN}$, so the concentrations of $\mathrm{HCN}$ in the treated space and environment post-application should be lower than those reported here.

\section{Concentration of $\mathrm{HCN}$ during fumigation}

Hydrogen cyanide was detected in the samples from the treated space of chambers that only contained EDN (i.e. devoid of a log). This was to be expected given that the source of EDN contained HCN. Following an EDN dose of $50 \mathrm{~g} \mathrm{~m}^{-3}$, the concentrations of $\mathrm{HCN}$ in the empty chamber at each temperature did not significantly change over time, and hence, data has been averaged over the measurement period that equated to $0.76 \pm 0.04 \mathrm{~g} \mathrm{~m}^{-3}(n=6)$ at $10{ }^{\circ} \mathrm{C}$ and $0.86 \pm 0.03 \mathrm{~g} \mathrm{~m}^{-3}$ at $20{ }^{\circ} \mathrm{C}$ (Fig. 3d). Compared to the empty chambers above, lower $\mathrm{HCN}$ concentrations were detected in the treated space of chambers containing $\log$ sections (Fig. 3c). The lower concentrations were evidently due to sorption since $\mathrm{HCN}$ has a relatively higher wood penetration ability compared to other fumigants (Douda et al. 2015; Stejskal et al. 2014). At $10{ }^{\circ} \mathrm{C}$, the concentration of $\mathrm{HCN}$ in the treated space ranged from 0.45 to $0.55 \mathrm{~g} \mathrm{~m}^{-3}$ (averaging $0.5 \pm 0.01 \mathrm{~g} \mathrm{~m}^{-3}$ ) during fumigation of $\log$ sections with no clear trend over time, whereas at $20{ }^{\circ} \mathrm{C}$, the $\mathrm{HCN}$ concentrations ranged from 0.41 to $0.99 \mathrm{~g} \mathrm{~m}^{-3}$ (averaging $0.75 \pm 0.09 \mathrm{~g} \mathrm{~m}^{-3}$; Table 1). However, concentrations did not change significantly $(P$ value $=0.055)$ during fumigation (Table 1$)$. Temperature did significantly $(P$ value $<0.001$, Wald/d.f. 17) influence the concentration of $\mathrm{HCN}$ in the treated space when logs were present, with a higher average concentration measured at $20{ }^{\circ} \mathrm{C}$ than $10{ }^{\circ} \mathrm{C}$ (Table 1). Although statistically significant, this difference in average 


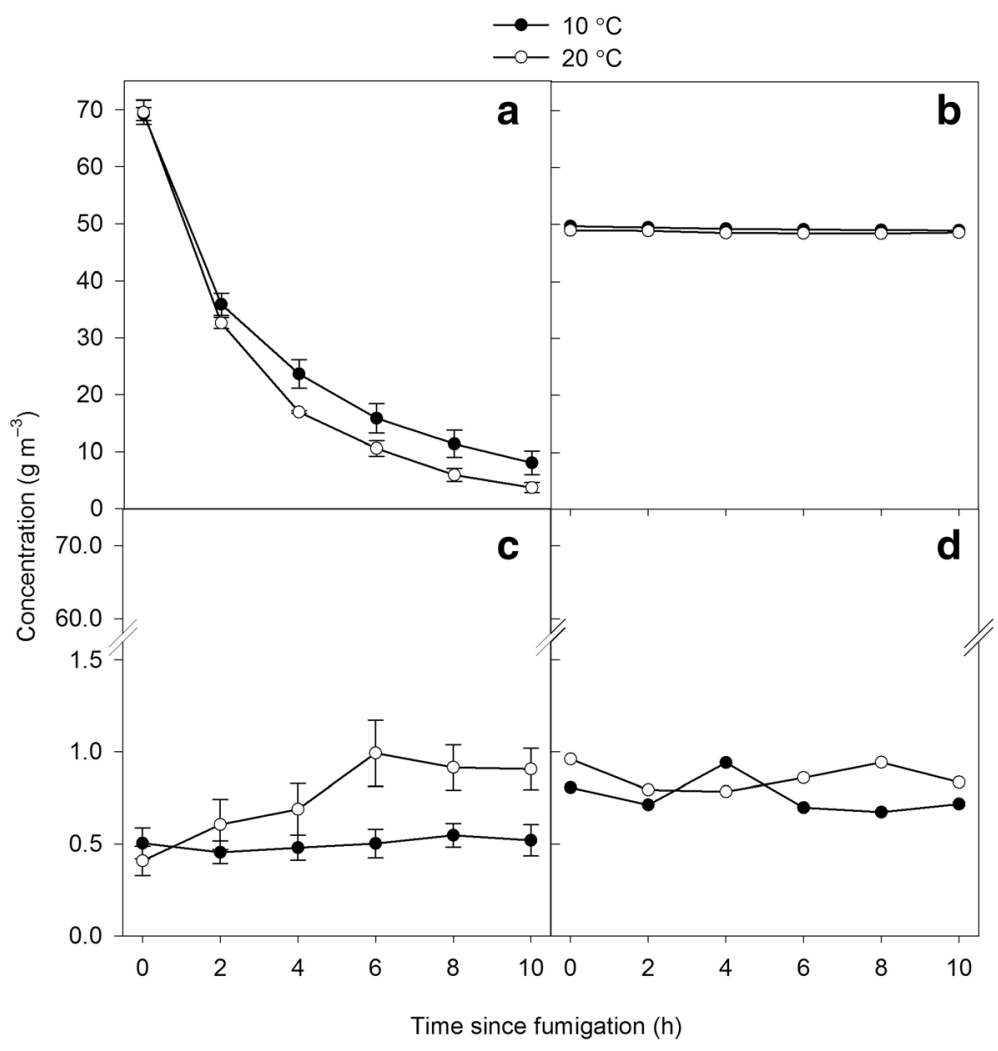

Fig. 3 Average concentrations of ethanedinitrile in the chambers a with $\log$ sections $(n=3)$ and $\mathbf{b}$ without log sections $(n=1)$ and hydrogen cyanide $\mathbf{c}$ with log sections $(n=3)$ and $\mathbf{d}$ without log sections $(n=1)$, during the fumigation of pine (Pinus radiata D.Don) log sections at 10 or $20^{\circ} \mathrm{C}$. Error bars represent the standard error of the mean

$\mathrm{HCN}$ concentration between treatment temperatures is commercially inconsequential as it equated to a difference of $0.25 \mathrm{~g} \mathrm{~m}^{-3}$.

The results of these tests demonstrate that $\mathrm{HCN}$ is not a significant breakdown product of EDN when used to treat commodities with high moisture contents, such as pine logs.

Park et al. (2014) used 48 to $158 \mathrm{~g} \mathrm{~m}^{-3}$ of EDN to fumigate Korean red pine logs with an approximate load factor of $50 \%$. Moisture content of the logs was 55.5 and $68.2 \%$ for the winter and spring trials, respectively, while 3 - $\mathrm{d}$ average temperatures were 4.4 and $6.1{ }^{\circ} \mathrm{C}$, respectively. The EDN used in that study had a $99 \%$ purity in balanced air and was also manufactured by Draslovka and marketed by BOC Australia. These authors did not detect $\mathrm{HCN}$ during their fumigations. Differences between the current results and those of Park et al. (2014) may be explained by the sensitivity of the analytical instrument used to measure $\mathrm{HCN}$, i.e. GC-MS (current study) vs. GC-FID (Park et al. 2014) and/or a higher purity of EDN reagent. Because Park et al. (2014) did not detect $\mathrm{HCN}$, these authors concluded that EDN is not converted to $\mathrm{HCN}$ during low-temperature fumigations. The results of the current study are consistent with this conclusion.

\section{Concentration of EDN during fumigation}

The initial concentration $(0 \mathrm{~h})$ of EDN in the treated space of empty chambers was 49.7 and $49.0 \mathrm{~g} \mathrm{~m}^{-3}$ at 10 and $20{ }^{\circ} \mathrm{C}$, respectively, which did not change

Table 1 Average concentration $\left(\mathrm{g} \mathrm{m}^{-3}\right.$ ) of hydrogen cyanide in the treated space during simulated fumigation of pine (Pinus radiata D.Don) logs at 10 or $20^{\circ} \mathrm{C}$

\begin{tabular}{|c|c|c|c|c|c|c|c|}
\hline & Time (h) & & & & & & \\
\hline Temperature $\left({ }^{\circ} \mathrm{C}\right)$ & 0 & 2 & 4 & 6 & 8 & 10 & Average \\
\hline 10 & $0.50 \mathrm{~ns}$ & $0.45 \mathrm{~ns}$ & $0.48 \mathrm{~ns}$ & $0.50 \mathrm{~ns}$ & $0.55 \mathrm{~ns}$ & $0.52 \mathrm{~ns}$ & $0.50 \mathrm{~b}$ \\
\hline 20 & $0.41 \mathrm{~ns}$ & $0.61 \mathrm{~ns}$ & $0.69 \mathrm{~ns}$ & $0.99 \mathrm{~ns}$ & $0.91 \mathrm{~ns}$ & $0.91 \mathrm{~ns}$ & $0.75 a$ \\
\hline
\end{tabular}

For average concentrations at respective temperatures $(n=3)$, values followed by a different letter are significantly different $(P$ value $<0.001)$, REML and LSD $5 \%$ (0.13). At respective temperatures, concentrations over time were not significantly (ns) different ( $P$ value 0.055$)$ 
significantly over time at either temperature (Fig. 3b). Initial concentrations of EDN in the chambers with $\log$ sections were $\approx 70 \mathrm{~g} \mathrm{~m}^{-3}$ (influenced by the load factor of $46 \pm 1.4 \%$ ). The concentration of EDN in the treatments using log sections decreased exponentially over time at both temperatures (Fig. 3a) while it remained constant in the chambers' devoid of logs. Previous fumigant studies have showed that these decreased concentrations over time occur due to sorption (Hall et al. 2017; Hall et al. 2015). At $10{ }^{\circ} \mathrm{C}, 8.0 \pm 2.0 \mathrm{~g} \mathrm{~m}^{-3}$ remained in the treated space after $10 \mathrm{~h}$, whereas only $3.7 \pm 0.9 \mathrm{~g} \mathrm{~m}^{-3}$ remained at $20{ }^{\circ} \mathrm{C}$. During fumigation, time was the most significant $(P$ value $<0.001$, Wald/d.f. 1842) factor influencing the concentration of EDN in the treated space. The decrease in concentration over time is due primarily to the adsorption and absorption of molecules onto and into the wood.

A higher rate of EDN loss was measured at $20{ }^{\circ} \mathrm{C}$ than at $10{ }^{\circ} \mathrm{C}(P$ value $<0.001$, Wald/d.f. 16$)$, whereby $5.3 \pm$ $1.4 \%$ and $11.6 \pm 3.2 \%$ of the initial concentration remained in the treated space after $10 \mathrm{~h}$ of fumigation, respectively (Fig. 3). This temperature-related difference in concentration is similar to that shown by Hall et al. (2015), who found that $9.4 \pm 0.4 \%$ of the initial EDN concentration remained in the treated space after $10 \mathrm{~h}$ for logs treated at $15{ }^{\circ} \mathrm{C}$. Hence, under these simulated commercial conditions, any decomposition of EDN to $\mathrm{HCN}$ is not likely to occur.

Very little is known about the breakdown products of EDN during or after fumigation. Various studies, such as Hwang et al. (1989), Hemminger et al. (1979) and Kingsley et al. (1984), have quantified the bonding and surface chemistry of EDN with single crystal metals such as $\mathrm{Pt}, \mathrm{Ni}$ and $\mathrm{Cu}$. These studies focused on the adsorption, desorption and decomposition of EDN on metal surfaces, and hence, the results are not transferable to the conditions that occur during the fumigation of commodities such as logs and sawn timber. While gaps remain in our knowledge about all the breakdown products of EDN during and after fumigation, our study clearly demonstrates that $\mathrm{HCN}$ is not produced in measurable amounts under the experimental conditions used in this current study.

Higher temperatures generally increase the sorption rate of fumigants because the activity of molecules increases, so their ability to diffuse and penetrate into the material improves (Dumas and Bond 1977; Hall et al. 2017; Ren et al. 2006). The results of the current study confirm that greater sorption rates can be expected during EDN fumigations of recently harvested pine logs at higher temperatures, with sorption of EDN increasing as the fumigation temperature increases. This is the first time that a temperature-dependent response has been reported for the treatment of logs with EDN. This temperature-dependent response differs from the results reported by Hall et al. (2017) for MB, where sorption rates were similar at both 10 and $20{ }^{\circ} \mathrm{C}$. These authors suggested that this difference in temperature was not sufficient to induce a measurable change in the activity of $\mathrm{MB}$ molecules, whereas this temperature difference does result in a measurable change in the activity of EDN molecules. In contrast, Ren et al. (2011) reported differences in the sorption rates of EDN and $\mathrm{MB}$ at $23-25{ }^{\circ} \mathrm{C}$ with $36 \%$ of the EDN and $30 \%$ of the $\mathrm{MB}$ remaining in the treated space after $48 \mathrm{~h}$. However, the results of Ren et al. (2011), Hall et al. (2017) and those reported in this current study cannot be compared directly because the treatment parameters of temperature, load factor, tree species, the treated wood (log or sawn timber) and the moisture content were different.

The variation in sorption rates at different temperatures affects the development of fumigation schedules because sorption rates must be factored into the amount of EDN applied to ensure an efficacious QPS treatment. Hall et al. (2017) suggested that the temperature-dependent differences in sorption rates can reduce the concentration in the treated space over time to directly influence the CT product required to kill the target insect at a given concentration.

Pranamornkith et al. (2014b) and Hall et al. (2015) proposed formulae that can be used to predict the rate of fumigant sorption for EDN under different temperature conditions in the development of QPS fumigation schedules for further testing. In addition, higher treatment temperatures generally require lower doses to achieve efficacy (Najar-Rodriguez et al. 2015), indicating that an understanding of the chemical activity and efficacy of a fumigant at different temperatures is critical in the development of fumigation schedules. The sorption results presented here can be combined with data from similar studies (Hall et al. 2015; Park et al. 2014; Ren et al. 2011) and the EDN toxicity data for forest insects (Najar-Rodriguez et al. 2015; Pranamornkith et al. 2014a) to select concentrations for testing to identify the minimum dose required to control forest insects at different temperatures and times.

By comparing the CT values for larvae of two longhorn species, $A$. ferus and A. glabripennis, to EDN $\left(19.50 \mathrm{~g} \mathrm{~h} \mathrm{~m}^{-3}\right)$ and $\mathrm{HCN}\left(17.67 \mathrm{~g} \mathrm{~h} \mathrm{~m}^{-3}\right)$, respectively (Najar-Rodriguez et al. 2015; Stejskal et al. 2014), it can be speculated that the toxicity of these compounds to larvae of these species may be similar. Therefore, the $\mathrm{HCN}$ impurity of $3.1 \%$, reported in this work, equates to a $\mathrm{CT}$ of $2.4 \mathrm{~g} \mathrm{~h} \mathrm{~m}^{-3} \mathrm{HCN}$ for a $50 \mathrm{~g} \mathrm{~m}^{-3}$ dose of EDN over a 3-h fumigation. By extrapolation of this data to the toxicity of these compounds to larvae of A. ferus, assuming equal toxicity, approximately $1.6 \%\left(0.3 / 19.50 \mathrm{~g} \mathrm{~h} \mathrm{~m}^{-3}\right)$ of the efficacy may be achieved by $\mathrm{HCN}$ under the conditions tested by Najar-Rodriguez et al. (2015). The effect of 
fumigation on the mortality of different types of insects and the relationship between the toxicity of insects to $\mathrm{EDN}$ and $\mathrm{HCN}$ warrant further investigation.

\section{Conclusions}

Our study, for the first time, demonstrates that either fumigation of pine logs with EDN does not result in the production of $\mathrm{HCN}$ or the concentration of $\mathrm{HCN}$ produced is not detectable as it is masked by the $\mathrm{HCN}$ that is endogenous to the EDN. Impacts on chemical efficacy, environmental emissions and worker safety due to the presence of $\mathrm{HCN}$ are therefore likely to be negligible. The concentration of $\mathrm{HCN}$ in the cylinder tested was $3.1 \%$ (or $34.6 \mathrm{~g} \mathrm{~m}^{-3}$ ). The manufacturer is now able to supply EDN with $<0.9 \% \mathrm{HCN}$, which will result in concentrations of $\mathrm{HCN}$ that are lower than those reported here. Furthermore, our results advance the knowledge required for the registration and commercialisation of EDN as a fumigant for the treatment of export logs.

\section{Abbreviations \\ $\mathrm{CT}$ : Concentration $\times$ time; EDN: Ethanedinitrile; EPA: Environmental Protection Authority; GC: Gas chromatograph; HCN: Hydrogen cyanide; MB: Methyl bromide; MS: Mass spectrometer; PLOT: Porous layer open tubular; QPS: Quarantine and pre-shipment; REML: Residual maximum likelihood; STIMBR: Stakeholders in Methyl Bromide Reduction}

\section{Acknowledgements}

This work was supported by Stakeholders in Methyl Bromide Reduction (STIMBR), using voluntary contributions from industry and New Zealand's B3 programme (Better Border Biosecurity, www.b3nz.org). Scientific inputs of Dr. Jack Armstrong are greatly appreciated.

\section{Funding}

Funding was provided by STIMBR.

\section{Authors' contributions}

All authors contributed substantially to the work reported here. $\mathrm{MH}$ and $\mathrm{AA}$ conducted the study. MH, AA and PP wrote the manuscript. All authors read and approved the final manuscript.

\section{Ethics approval and consent to participate}

Not applicable

\section{Competing interests}

The authors declare that they have no competing interests.

\section{Publisher's Note}

Springer Nature remains neutral with regard to jurisdictional claims in published maps and institutional affiliations.

\section{Author details}

${ }^{1}$ The New Zealand Institute for Plant \& Food Research Limited, Private Bag 11600, Palmerston North, New Zealand. ${ }^{2}$ Apreso, Po Box 2407, Palmerston North, New Zealand. ${ }^{3}$ Start Afresh, PO Box 4606, Mt Maunganui, New Zealand

Received: 4 September 2017 Accepted: 15 May 2018

Published online: 08 June 2018

\section{References}

BOC (n.d.) EDN Fumigas. http://cropscience.lindegas.com/internet.lg.cropprotection. global/en/images/MPG_BA_Fumigants\%20EDN\%20datasheet_Timber_A4\%20 leaflet_VIEW903_115753.v=1.0. Viewed 21 May 2018
Brash, DW, Armstrong, JW, Waddell, BC (2013). Ethanedinitrile (EDN) as a potential quarantine disinfestation treatment for New Zealand export logs and sawn timber. Palmerston North: Plant \& Food Research.

Douda, O, Zouhar, M, Maňasová, M, Dlouhý, M, Lišková, J, Ryšánek, P. (2015). Hydrogen cyanide for treating wood against pine wood nematode (Bursaphelenchus xylophilus): results of a model study. Journal of Wood Science, 61(2), 204-210. https://doi.org/10.1007/s10086-014-1452-9.

Duarte-Sierra, A, Aispuro-Hernández, E, Vargas-Arispuro, I, Islas-Osuna, MA, González-Aguilar, GA, Martínez-Téllez, MÁ. (2016). Quality and PR gene expression of table grapes treated with ozone and sulfur dioxide to control fungal decay. Journal of the Science of Food and Agriculture, 96(6), 2018-2024. https://doi.org/10.1002/jsfa.7312.

Dumas, T, \& Bond, EJ. (1977). Penetration, sorption, and desorption of fumigant in the treatment of food materials with a methyl bromide-acrylonitrile mixture. Journal of Agricultural and Food Chemistry, 25(3), 677-680. https://doi.org/10. 1021/jf60211a041.

Eaton, J (2009). Determination of cyanide in drinking water by GC/MS headspace analysis. Augusta: H\&E Testing Laboratory.

Emekci, M (2010). Quo Vadis the fumigants? (pp. 303-313). Estoril: Paper presented at the Proceedings of the 10th International Working Conference on Stored Product Protection.

EPA-NZ (2012). User guide for thresholds and classifications under the Hazardous Substances and New Organisms Act 1996. https://www.epa.govt.nz/assets/ Uploads/Documents/Hazardous-Substances/Guidance/thresholdsclassification-guidance.pdf. Accessed 21 May 2018.

Fields, PG, Neven, LG, Johnson, J (2004). Practical alternatives to methyl bromide for use as quarantine and pre-shipment treatments in North America, (pp. 119122). Lisbon: Paper presented at the Fifth International Conference on Alternatives to Methyl Bromide.

Hall, M, Najar-Rodriguez, A, Adlam, A, Hall, A, Brash, D. (2017). Sorption and desorption characteristics of methyl bromide during and after fumigation of pine (Pinus radiata D. Don) logs. Pest Management Science, 73(5), 874-879. https://doi.org/10.1002/ps.4355.

Hall, M, Najar-Rodriguez, A, Pranamornkith, T, Adlam, A, Hall, A, Brash, D. (2015). Influence of dose, bark cover and end-grain sealing on ethanedinitrile $\left(\mathrm{C}_{2} \mathrm{~N}_{2}\right)$ sorption by pine (Pinus radiata D. Don) logs. New Zealand Plant Protection, 68, 13-18

Hemminger, JC, Muetterties, EL, Somorjai, GA. (1979). A coordination chemistry study of a nickel surface. The chemistry of nickel (111) with triply bonded molecules. Journal of the American Chemical Society, 101(1), 62-67. https://doi. org/10.1021/ja00495a011.

Hwang, SY, Kong, ACF, Schmidt, LD. (1989). Surface chemistry of carbon-nitrogen bonds on rhodium(111). 1. Ethanedinitrile and methylamine. The Journal of Physical Chemistry, 93(26), 8327-8333. https://doi.org/10.1021/j100363a011.

Kingsley, JR, Dahlgren, D, Hemminger, JC. (1984). Coadsorption chemistry of $\mathrm{H}_{2}$ and $\mathrm{C}_{2} \mathrm{~N}_{2}$ on $\mathrm{Pt}(111)$ : a common intermediate in the hydrogenation of cyanogen and the dehydrogenation of ethylenediamine on Pt(111). Surface Science, 139(2), 417-429. https://doi.org/10.1016/0039-6028(84)90060-8.

Murphy, KE, Schantz, MM, Butler, TA, Benner, BA, Wood, LJ, Turk, GC. (2006). Determination of cyanide in blood by isotope dilution gas chromatographymass spectrometry. Clinical Chemistry, 52(3), 458-467. https://doi.org/10.1373/ clinchem.2005.061002.

Najar-Rodriquez, AJ, Hall, MKD, Adlam, AR, Hall, AJ, Burgess, SB, Somerfield, KG, Page, BBC, Brash, DW. (2015). Developing new fumigation schedules for the phytosanitary treatment of New Zealand export logs: comparative toxicity of two fumigants to the burnt pine longhorn beetle, Arhopalus ferus. New Zealand Plant Protection, 68, 19-25.

O'Brien, I. G., Desmarchelier, F. J. M., \& Yonglin, R. (1999). Cyanogen fumigants and methods of fumigation using cyanogen: US Patents CA2192959A1.

Park, CG, Son, J-K, Lee, B-H, Cho, JH, Ren, Y. (2014). Comparison of ethanedinitrile $\left(\mathrm{C}_{2} \mathrm{~N}_{2}\right)$ and metam sodium for control of Bursaphelenchus xylophilus (Nematoda: Aphelenchidae) and Monochamus alternatus (Coleoptera: Cerambycidae) in naturally infested logs at low temperatures. Journal of Economic Entomology, 107(6), 2055-2060. https://doi.org/10.1603/EC14009.

Pranamornkith, T, Hall, MKD, Adlam, AR, Somerfield, KG, Page, BBC, Hall, AJ, Brash DW. (2014b). Effect of fumigant dose, timber moisture content, end-grain sealing, and chamber load factor on sorption by sawn timber fumigated with ethanedinitrile. New Zealand Plant Protection, 67, 66-74.

Pranamornkith, T, Hall, MKD, Najar-Rodriguez, A, Adlam, AR, Somerfield, KG, Page, BBC, Hedderley, DI, Brash, DW. (2014a). Ethanedinitrile: potential methyl 
bromide alternative to control Arhopalus ferus (Mulsant) in New Zealand sawn timber exports. New Zealand Plant Protection, 67, 75-79.

Ren, Y, Lee, B, Padovan, B. (2011). Penetration of methyl bromide, sulfuryl fluoride, ethanedinitrile and phosphine into timber blocks and the sorption rate of the fumigants. Journal of Stored Products Research, 47(2), 63-68. https://doi. org/10.1016/j.jspr.2010.04.006

Ren, Y, Wang, Y, Barak, AV, Wang, X, Liu, Y, Dowsett, HA. (2006). Toxicity of ethanedinitrile to Anoplophora glabripennis (Coleoptera: Cerambycidae) larvae. Journal of Economic Entomology, 99(2), 308-312. https://doi.org/10. 1093/jee/99.2.308.

Stejskal, V, Douda, O, Zouhar, M, Manasova, M, Dlouhy, M, Simbera, J, Aulicky, R. (2014). Wood penetration ability of hydrogen cyanide and its efficacy for fumigation of Anoplophora glabripennis, Hylotrupes bajulus (Coleoptera), and Bursaphelenchus xylophilus (Nematoda). International Biodeterioration \& Biodegradation, 86(Part C), 189-195. https:/doi.org/10.1016/j.ibiod.2013.08.024.

\section{Submit your manuscript to a SpringerOpen ${ }^{\circ}$} journal and benefit from:

- Convenient online submission

- Rigorous peer review

- Open access: articles freely available online

- High visibility within the field

- Retaining the copyright to your article

Submit your next manuscript at $>$ springeropen.com 